\title{
Removal of heavy metals from acid mine drainage by native natural clay minerals, batch and continuous studies
}

\author{
Abbas Esmaeili ${ }^{1} \cdot$ Mohammad Mobini $^{1} \cdot$ Hadi Eslami $^{1}$ D \\ Received: 20 October 2018 / Accepted: 6 May 2019 / Published online: 16 May 2019 \\ (c) The Author(s) 2019
}

\begin{abstract}
Acid mine drainage (AMD) properties are high acidity, high concentration of sulfate and containing a wide range of heavy metal ions. This study was performed to remove the copper, zinc and nickel from AMD by four native natural clay minerals including bentonite, two types of volcanic ash soil (VAS-I, VAS-II) and red soil using both batch and continuous techniques. The characteristics of adsorbents were investigated by X-ray fluorescence and X-ray diffraction analysis. In batch technique, clay minerals adsorbents were used in different dosages. However, in continuous technique one natural clay mineral (volcanic ash soil) was used. Results showed that the order of capacity of adsorption by four types of minerals was: bentonite $>$ red earth $>$ VAS-I $>$ VAS-II. The adsorption affinity order of the metal ions by all sorbents was $\mathrm{Ni}>\mathrm{Cu}>\mathrm{Zn}$. In continuous technique, the critical concentration $\left(C / C_{0}=0.1\right)$ of copper, zinc and nickel in the flow rate $0.8 \mathrm{~mL} / \mathrm{min}$ was 350,160 and $170 \mathrm{~min}$, respectively. Therefore, fixed-bed column experiments showed that volcanic ash soils have the characteristics of simplicity of operation, little sludge production, suitability for low concentrations, flexibility and excellence for continuous and bath operations.
\end{abstract}

Keywords Adsorption $\cdot$ Heavy metal removal $\cdot$ Natural clay minerals $\cdot$ Acid mine drainage

\section{Introduction}

Acid mine drainage (AMD) is one of the major problems in the present world, which is produced by the mining activities (Idaszkin et al. 2017; Jones and Cetin 2017). AMD is created as a result of geochemical reaction; when sulfide minerals are exposed to the atmosphere, they are generated by the process of oxidation (Rios et al. 2008; Sánchez-Andrea et al. 2014). The main characteristics of AMD are high acidity, high concentration of sulfate and containing a wide range of heavy metal ions such as $\mathrm{Cu}^{2+}, \mathrm{Ni}^{2+}, \mathrm{Zn}^{2+}, \mathrm{Cd}^{2+}$ and $\mathrm{Pb}^{2+}$ (Liao et al. 2017; McCauley et al. 2009). If it is discharged

Hadi Eslami

hadieslami1986@yahoo.com; H.eslami@rums.ac.ir

Abbas Esmaeili

esmailiabbas@yahoo.com

Mohammad Mobini

mobinilk@gmail.com

1 Department of Environmental Health Engineering, Occupational Environment Research Center, School of Health, Rafsanjan University of Medical Sciences, Rafsanjan, Iran into the environment without neutralization and removal of hazardous heavy metals, due to these heavy metals not biodegradable and accumulating in living organisms, they can cause a serious adverse effect on human health and ecological resources (Cui et al. 2012; Eslami et al. 2018b; Măicăneanu et al. 2013; Rakotonimaro et al. 2017).

There are several methods for the removal of heavy metals from acid mine drainage such as chemical precipitation, oxidation, hydrolysis, reverse osmosis, solvent extraction, ion exchange, neutralization, electrochemical remediation, adsorption and biosorption (Eslami et al. 2018a; Kalhor et al. 2018; Mohan and Chander 2006; Tolonen et al. 2014). Absorption is a popular and highly effective method for the removal of heavy metals from wastewaters and AMD (Motsi et al. 2009; Rafati et al. 2018a; Zhang 2011). The advantages of adsorption method include simplicity of operation, access to the adsorbent materials, not requiring any chemical substances and little sludge production (Božić et al. 2013; Eren et al. 2009; Khosravi et al. 2018; Malamis and Katsou 2013). Adsorption of heavy metals has been developed by various types of low-cost, natural and effective adsorbents, such as fly ash, tree bark, tea leaves, natural zeolite and clay minerals (Bachale et al. 2016; De Gisi et al. 2016; Rafati et al. 
2018b). Natural clay and clay minerals such as bentonite and red soils have a small particle size and porous structure with a high specific surface area, which have high efficiency for adsorption and cation exchange capacity (Rafati et al. 2016; Uddin 2017). Natural clay minerals due to their lowcost and high availability are used for numerous adsorption researches (Anirudhan et al. 2012; Anna et al. 2015; Melichová and Hromada 2013; Vieira et al. 2010b). Recently, natural mineral clays were investigated for the removal of copper $\mathrm{Cu}$ (II) (Zacaroni et al. 2015), arsenic (V) (Bentahar et al. 2016), cadmium (II), lead (II) and chromium (VI) ions from the aqueous environment (Khan and Singh 2010).

Therefore, this study was performed to remove the copper, zinc and nickel from AMD of copper mining (Rafsanjan, Iran) by natural clay minerals adsorbents including bentonite, two types of volcanic ash soils (VAS-I, VAS-II) and red earth in batch and continuous experiments.

\section{Materials and methods}

\section{Preparation of adsorbents}

In this study, we used four natural clay minerals including bentonite, two types of volcanic ash soil (VAS-I, VAS-II) and red earth that were collected from Kerman province which is located in the southeast part of Iran. First, they were crushed using a jaw crusher (Pulverisette, Fritsch, Germany) and then sieved, and a particle size less than 50 mesh was selected for tests. Chemical and mineralogical composition of NNB is identified by X-ray fluorescence (XRF) and X-ray diffraction (XRD) (Philips PW1730, The Netherlands) analysis. The cation exchange capacity (CEC) of NNB was measured by methylene blue index, according to the ASTM C 837-81 (Calabria et al. 2013).

\section{Materials}

All chemical reagents used in this study were obtained from Merck Company (Germany) with analytical grade. Acid mine drainage (AMD) was collected from the Sarcheshmeh copper mine located in Rafsanjan, Iran. The chemical characteristics of acid drainage are given in Table 1.

\section{Experiment procedure}

This study was carried out at room temperature using both continuous and batch techniques in a laboratory scale. In batch technique, four natural clay minerals were used including bentonite, two types of volcanic ash soil (VAS-I, VASII) and red earth in different doses $(20,30,40$ and $60 \mathrm{mg} / \mathrm{l})$, and solutions volume $(50 \mathrm{ml})$ was mixed in $300-\mathrm{ml}$ flatbottom Erlenmeyer flasks and then shaken for $300 \mathrm{~min}$ with
Table 1 Chemical

characteristics of acid drainage

\begin{tabular}{ll}
\hline Composition & $\begin{array}{l}\text { Concen- } \\
\text { tration } \\
(\mathrm{mg} / \mathrm{l})\end{array}$ \\
\hline $\mathrm{Cu}$ & 80 \\
$\mathrm{Zn}$ & 13 \\
$\mathrm{Ni}$ & 1 \\
$\mathrm{pH}$ & 4.6 \\
$\mathrm{EC}(\mathrm{mmhos} / \mathrm{cm})$ & 1795 \\
\hline
\end{tabular}

a speed of $150 \mathrm{rpm}$ on a rotary shaker. The suspensions were filtered using a filter paper $(0.45 \mu \mathrm{m})$, and then, metal ion concentration in filtrate was determined. Atomic absorption spectrometry (AAS) was used to measure the concentration of metals (Varian AA-975 and AA-1275 models). In this study, the following conditions were constant in all experiments: temperature $\left(27 \pm 1{ }^{\circ} \mathrm{C}\right)$, particle size ( $\left.\leq 50 \mathrm{mesh}\right)$, solution volume $(50 \mathrm{ml})$ and rate of shaking $(150 \mathrm{rpm})$. The percent of metal ions removal by adsorbents was calculated by the following equation (Eq. 1):

$\% \mathrm{MS}=\frac{C_{\mathrm{O}}-C_{\mathrm{e}}}{C_{\mathrm{O}}} \times 100$

Mass balance equation is used to calculate the capacity of the adsorbents:

$q_{\mathrm{e}}=\frac{C_{0}-C_{\mathrm{e}}}{m} \times V$

where $q_{\mathrm{e}}$ is the amount of metal ions absorbed on adsorbents (mg/g); $C_{0}$ and $C_{\mathrm{e}}$ are the initial and equilibrium concentration $(\mathrm{mg} / \mathrm{L})$ of metal ions, respectively; $V$ is the volume of $\operatorname{AMD}(L)$; and $\mathrm{m}$ is mass of adsorbent $(g)$.

The column studies were carried out by one adsorbent (volcanic ash soli). Column experiments were performed in a glass column with a height of $40 \mathrm{~cm}$ which was packed to a height of 15 and $26 \mathrm{~cm}$ and internal diameter of 2.5 and $1.5 \mathrm{~cm}$. The tests were conducted in two flow rates $(0.8$ and $1.4 \mathrm{ml} / \mathrm{min}$ and particle size selected in the range $10-20 \mu \mathrm{m}$.

\section{Results and discussion}

\section{Adsorbents characteristics}

Chemical composition and CEC and mineralogical composition of clay minerals are given in Tables 2 and 3, respectively. Chemical composition analysis by XRF showed that the main compounds in the adsorbents were silica $\left(\mathrm{SiO}_{2}\right)$ and alumina $\left(\mathrm{Al}_{2} \mathrm{O}_{3}\right)$. Based on the main elements of this mineral clays ( $\mathrm{Si}$ and $\mathrm{Al}$ ), therefore, they are in the smectite clay group (Pereira de Araujo et al. 2013). Smectite group 
Table 2 Chemical analysis and cation exchange capacity of dried clay minerals adsorbents

\begin{tabular}{lcccl}
\hline Composition & wt $\%$ & & & \\
\cline { 2 - 5 } & Bentonite & VAS-I & VAS-II & Red soil \\
\hline $\mathrm{SiO}_{2}$ & 64 & 58 & 58.5 & 58 \\
$\mathrm{Al}_{2} \mathrm{O}_{3}$ & 6.5 & 10 & 10.5 & 15.2 \\
$\mathrm{Fe}_{2} \mathrm{O}_{3}$ & 3.6 & 3.6 & 3.1 & 3.1 \\
$\mathrm{CaO}$ & 2.2 & 2.2 & 3.4 & 4.9 \\
$\mathrm{MgO}$ & 3 & 1.8 & 1.6 & 0.8 \\
$\mathrm{Na}$ & 2. & 5.3 & 4.5 & - \\
$\mathrm{K}_{2} \mathrm{O}$ & 2.2 & 1.4 & 1.8 & 0.1 \\
$\mathrm{LOI}$ & 0.5 & 5.3 & 6.7 & 10.7 \\
$\mathrm{CEC}$ & 10.7 & 377.4 & 174.6 & 114.4 \\
\hline
\end{tabular}

LOI loss of ignition

Table 3 Mineralogical composition of clay minerals adsorbents by XRD analysis

\begin{tabular}{lll}
\hline Adsorbents & Mineral & Chemical formula \\
\hline Bentonite & Quartz & $\mathrm{SiO}_{2}$ \\
& Illite & $\mathrm{K}_{0.5}(\mathrm{Al}, \mathrm{Mg})_{3}(\mathrm{Si}, \mathrm{Al})_{4} \mathrm{O}_{10}(\mathrm{OH})_{2}$ \\
& Montmorillonite & $\mathrm{K}_{0.5} \mathrm{Al}_{2}(\mathrm{Si}, \mathrm{Al})_{4} \mathrm{O}_{10}(\mathrm{OH})_{2} \cdot \mathrm{H}_{2} \mathrm{O}$ \\
VAS-I & Quartz & $\mathrm{SiO}_{2}$ \\
& Bentonite & $\mathrm{K}(\mathrm{Fe}, \mathrm{Mg}) \mathrm{AlSi}_{3} \mathrm{O}_{10}(\mathrm{OH})_{2}$ \\
& Plagioclases & $(\mathrm{Ca}, \mathrm{Na})(\mathrm{Si}, \mathrm{Al})_{4} \mathrm{O}_{8}$ \\
VAS-II & Quartz & $\mathrm{SiO}_{2}$ \\
& Plagioclases & $(\mathrm{Ca}, \mathrm{Na})(\mathrm{Si}, \mathrm{Al})_{4} \mathrm{O}_{8}$ \\
& Illite & $\mathrm{K}_{0.5}(\mathrm{Al}, \mathrm{Mg})_{3}(\mathrm{Si}, \mathrm{Al})_{4} \mathrm{O}_{10}(\mathrm{OH})_{2}$ \\
Red soil & Quartz & $\mathrm{SiO}_{2}$ \\
& Plagioclases & $\left(\mathrm{Ca}_{2}, \mathrm{Na}\right)(\mathrm{Si}, \mathrm{Al})_{4} \mathrm{O}_{8}$ \\
& Kaolinite & $\mathrm{Al}_{2} \mathrm{Si}_{2} \mathrm{O}_{5}(\mathrm{OH})_{4}$ \\
& Hematite & $\mathrm{Fe}_{2} \mathrm{O}_{3}$ \\
& Calcite & $\mathrm{CaCO}_{3}$ \\
\hline
\end{tabular}

compared with other clays have high cation exchange capacity, high specific surface area and suitable adsorption efficiency (Uddin 2017). CEC of mineral clays adsorbents has a high cation exchange capacity to adsorb cationic heavy metal such as copper, zinc and nickel (Zhu et al. 2016).

\section{Batch study}

Effects of adsorbent dose on removal efficiency of bentonite, VAS-I, VAS-II and red earth are shown in Figs. 1, 2,3 and 4, respectively. With increasing amount of absorbents, increases removal of copper, nickel and zinc ions from AMD. Moreover, increasing amount of absorbents results in increased available site in solution. Therefore, the adsorption of surface area increased for metal ions uptake (Karapinar and Donat 2009). In addition to the

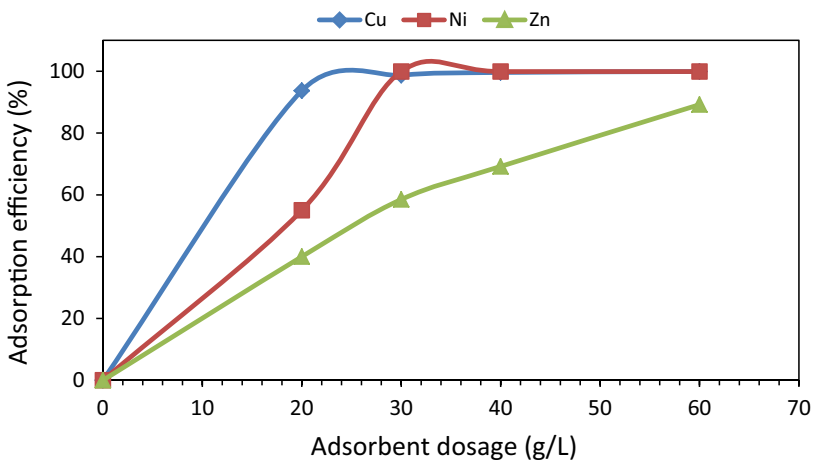

Fig. 1 Adsorption of heavy metals (copper, nickel and zinc) on bentonite

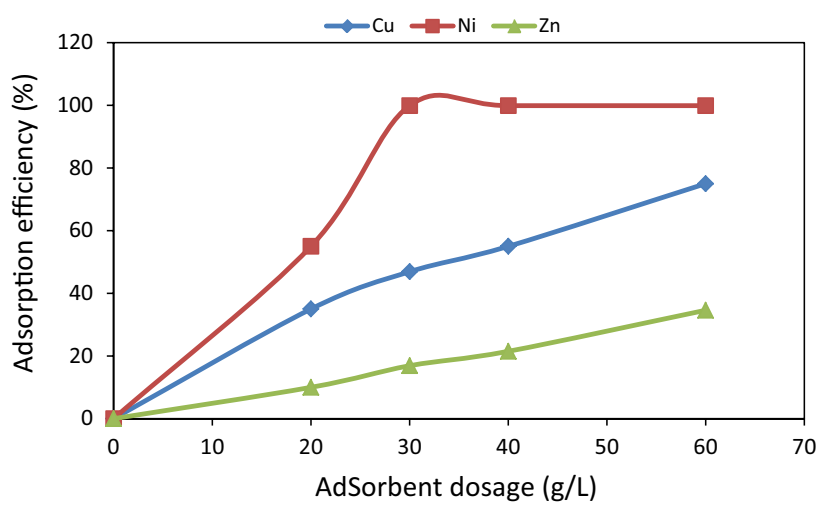

Fig. 2 Adsorption of heavy metals (copper, nickel and zinc) on VAS-I

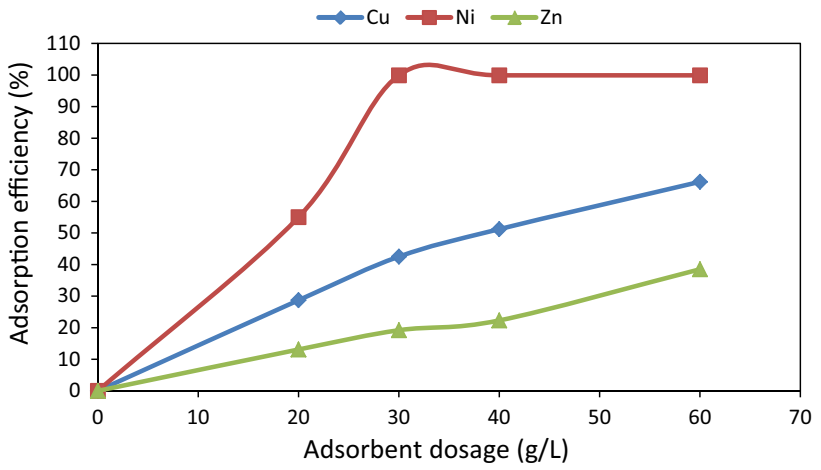

Fig. 3 Adsorption of heavy metals (copper, nickel and zinc) on VASII

removal of metal ions, neutralization process is occurred. Several investigators have confirmed these results (Jiang et al. 2006; Sen and Gomez 2011). Results showed that the order of capacity of adsorption by four types of minerals was: bentonite $>$ red earth $>$ volcanic ash soils. Type of natural clay mineral has a significant effect on the removal of heavy metal ions from water and wastewater (Malamis and Katsou 2013). In most cases, in addition 


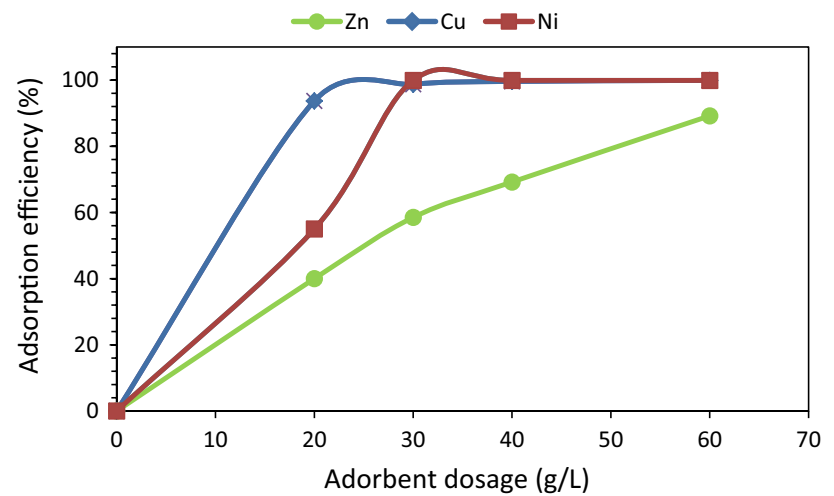

Fig. 4 Adsorption of heavy metals (copper, nickel and zinc) on red soil

to the ability of clay mineral for absorbent of metal ions, must be considers other characteristics of them. The most important properties are cost, efficiency, simplicity of operation, access to the adsorbent, the availability of materials, little sludge production, suitability for low concentrations, flexibility and excellence for continuous and bath operations (Božić et al. 2013; Eren et al. 2009; Vieira et al. 2010a). Sometimes can be increase the adsorption capacity by the chemical and thermal modification methods (Malamis and Katsou 2013). The results showed that red earth and bentonite have high capability for removing copper, zinc and nickel from AMD. The removal efficiency of copper, zinc and nickel by bentonite at dose $60 \mathrm{~g} / \mathrm{l}$ was $99.9 \%, 89.2 \%$ and $99.9 \%$, respectively. The adsorption affinity order of the metal ions by all sorbents was $\mathrm{Ni}>\mathrm{Cu}>\mathrm{Zn}$. Many studies show which mineral type has deferment of capacity for the removal of heavy metal ions from aqueous solution (Malamis and Katsou 2013).

Also, the $\mathrm{pH}$ of the solutions increases with increasing amount of adsorbents. $\mathrm{pH}$ is one of the most important factors in adsorption metal ions from aqueous solution (Uddin 2017). $\mathrm{pH}$ of solution has significantly effects on the number of $\mathrm{H}+$ ions, the characteristic of clay minerals and chemistry of metal (Malamis and Katsou 2013). It has also the effect on the process of precipitation and formation of ligands (Saravanan et al. 2013). At low pH, there are a large number of $\mathrm{H}^{+}$ions in solution which compete with metal ions for active sites on the adsorbent; consequently, the removal of metals is less (Anirudhan et al. 2012; Jiang et al. 2010). With increasing $\mathrm{pH}$, the number of $\mathrm{H}^{+}$ions is reduced and then the competition between $\mathrm{H}^{+}$ions and metal ions for adsorption sites decreased. Therefore, uptake of the heavy metals into absorbents was increased (Eloussaief and Benzina 2010; Jiang et al. 2010; Saravanan et al. 2013).

\section{Continuous study}

In fixed-bed column studies, for the determination of dynamic and operation response the behavior of breakthrough curves is important; therefore, in these studies adsorption data are described by using breakthrough curves (Atar et al. 2012). Figures 5 and 6 show the breakthrough curves for ions of copper, zinc and nickel. According to Fig. 5, the critical concentration $\left(C / C_{0}=0.1\right)$ of copper, zinc and nickel in the flow rate $0.8 \mathrm{ml} / \mathrm{min}$ is equal to 350,160 and $170 \mathrm{~min}$, respectively. In the flow rate $1.4 \mathrm{ml} / \mathrm{min}$, the critical concentration of copper, zinc and nickel was reduced and almost became half of the previous flow rate.

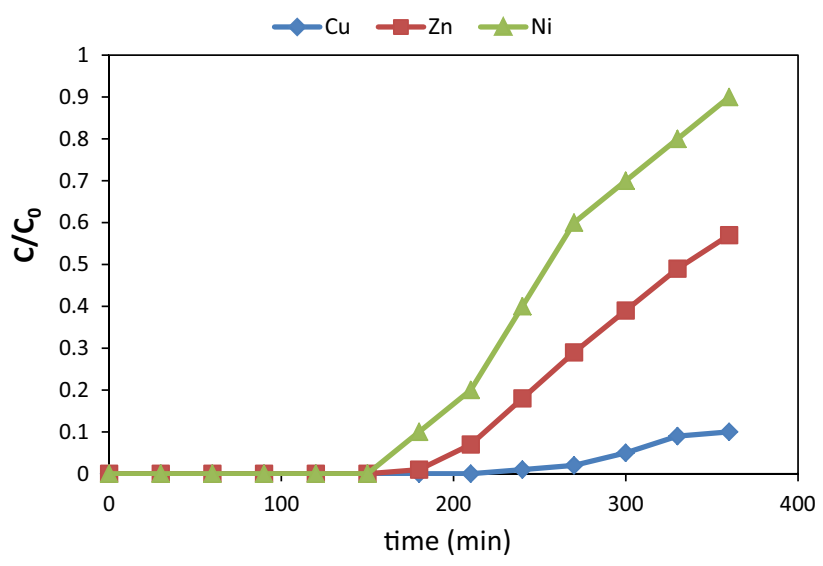

Fig. 5 Breakthrough curve for the adsorption copper, nickel and zinc on VAS-I (flow rate $=0.8 \mathrm{ml} / \mathrm{min} ; T=27 \pm 1{ }^{\circ} \mathrm{C}$ )

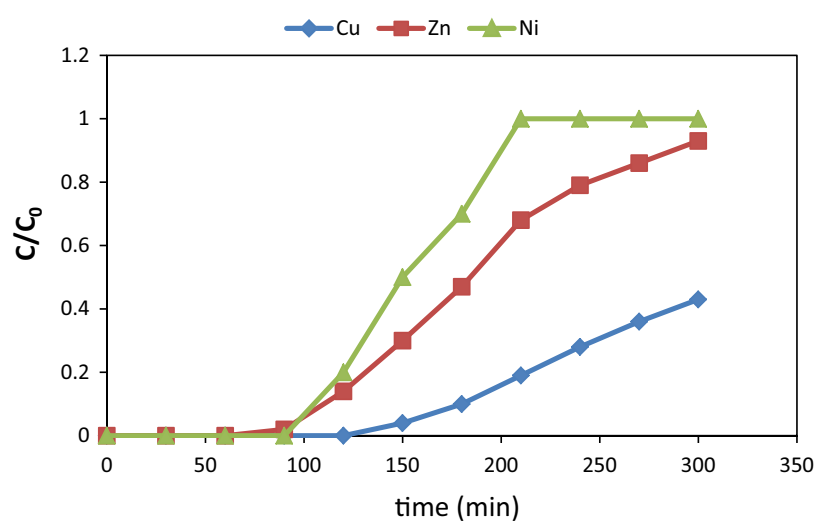

Fig. 6 Breakthrough curve for the adsorption copper, nickel and zinc on VAS-I (flow rate $=1.4 \mathrm{ml} / \mathrm{min} ; T=27 \pm 1{ }^{\circ} \mathrm{C}$ ) 


\section{Conclusion}

Results showed that the order of capacity of adsorption by four types of minerals is: bentonite $>$ red earth $>$ volcanic ash soils. The percentage of removal of copper, zinc and nickel by bentonite at dose $60 \mathrm{~g} / \mathrm{l}$ was $99.9 \%, 89.2 \%$ and $99.9 \%$, respectively. Also, in all tests the $\mathrm{pH}$ of final solution increased and neutralization process is occurred. The fixed-bed column tests showed that volcanic ash soils have the characteristics of simplicity of operation, little sludge production, suitability for low concentrations, flexibility and excellence for continuous and bath operations.

Acknowledgements The authors would like to thank Mr. Naser Nobari, the Manager of National Iranian Copper Industries (N.I.C.I) Co. R\&D Division, and Mr. H. Khodadadi, the Chief of N.I.C.I. Co. Central Laboratory, for their cooperation.

\section{Compliance with ethical standards}

Conflict of interest The authors declare that they have no conflict of interest.

Open Access This article is distributed under the terms of the Creative Commons Attribution 4.0 International License (http://creativeco mmons.org/licenses/by/4.0/), which permits unrestricted use, distribution, and reproduction in any medium, provided you give appropriate credit to the original author(s) and the source, provide a link to the Creative Commons license, and indicate if changes were made.

\section{References}

Anirudhan T, Bringle C, Radhakrishnan P (2012) Heavy metal interactions with phosphatic clay: kinetic and equilibrium studies. Chem Eng J 200:149-157

Anna B, Kleopas M, Constantine S, Anestis F, Maria B (2015) Adsorption of $\mathrm{Cd}(\mathrm{II}), \mathrm{Cu}(\mathrm{II}), \mathrm{Ni}(\mathrm{II})$ and $\mathrm{Pb}(\mathrm{II})$ onto natural bentonite: study in mono-and multi-metal systems. Environ Earth Sci 73:5435-5444

Atar N, Olgun A, Wang S (2012) Adsorption of cadmium(II) and zinc(II) on boron enrichment process waste in aqueous solutions: batch and fixed-bed system studies. Chem Eng J 192:1-7

Bachale S, Sharma S, Sharma A, Verma S (2016) Removal of lead(II) from aqueous solution using low cost adsorbent: a review. Int $\mathbf{J}$ Appl Res 2:523-527

Bentahar Y, Hurel C, Draoui K, Khairoun S, Marmier N (2016) Adsorptive properties of Moroccan clays for the removal of arsenic(V) from aqueous solution. Appl Clay Sci 119:385-392

Božić D, Gorgievski M, Stanković V, Štrbac N, Šerbula S, Petrović N (2013) Adsorption of heavy metal ions by beech sawdustkinetics, mechanism and equilibrium of the process. Ecol Eng 58:202-206

Calabria A, Amaral N, Ladeira Q, Cota S, Silva S (2013) Determination of the cation exchange capacity of the bentonite exposed to the hyperalkaline fluid. In: International nuclear Atlantic conference-INAC 2013 Recife, PE, Brazil, November 24-29

Cui M, Jang M, Cho S-H, Khim J, Cannon FS (2012) A continuous pilot-scale system using coal-mine drainage sludge to treat acid mine drainage contaminated with high concentrations of $\mathrm{Pb}, \mathrm{Zn}$, and other heavy metals. J Hazard Mater 215:122-128

De Gisi S, Lofrano G, Grassi M, Notarnicola M (2016) Characteristics and adsorption capacities of low-cost sorbents for wastewater treatment: a review. Sustain Mater Technol 9:10-40

Eloussaief M, Benzina M (2010) Efficiency of natural and acid-activated clays in the removal of $\mathrm{Pb}$ (II) from aqueous solutions. J Hazard Mater 178:753-757

Eren E, Afsin B, Onal Y (2009) Removal of lead ions by acid activated and manganese oxide-coated bentonite. J Hazard Mater 161:677-685

Eslami H, Ehrampoush MH, Esmaeili A, Ebrahimi AA, Salmani MH, Ghaneian MT, Falahzadeh H (2018a) Efficient photocatalytic oxidation of arsenite from contaminated water by $\mathrm{Fe}_{2} \mathrm{O}_{3}-\mathrm{Mn}_{2} \mathrm{O}_{3}$ nanocomposite under UVA radiation and process optimization with experimental design. Chemosphere 207:303-312

Eslami H, Ehrampoush MH, Falahzadeh H, Hematabadi PT, Khosravi R, Dalvand A, Esmaeili A, Taghavi M, Ebrahimi AA (2018b) Biodegradation and nutrients removal from greywater by an integrated fixed-film activated sludge (IFAS) in different organic loadings rates. AMB Express 8:3

Idaszkin YL, Carol E, del Pilar AM (2017) Mechanism of removal and retention of heavy metals from the acid mine drainage to coastal wetland in the Patagonian marsh. Chemosphere 183:361-370

Jiang K, Sun T, Sun L, Li H (2006) Adsorption characteristics of copper, lead, zinc and cadmium ions by tourmaline. J Environ Sci 18:1221-1225

Jiang M, Jin X, Lu X-Q, Chen Z (2010) Adsorption of Pb(II), Cd(II), $\mathrm{Ni}(\mathrm{II})$ and $\mathrm{Cu}(\mathrm{II})$ onto natural kaolinite clay. Desalination 252:33-39

Jones SN, Cetin B (2017) Evaluation of waste materials for acid mine drainage remediation. Fuel 188:294-309

Kalhor MM, Rafati AA, Rafati L, Rafati AA (2018) Synthesis, characterization and adsorption studies of amino functionalized silica nano hollow sphere as an efficient adsorbent for removal of imidacloprid pesticide. J Mol Liq 266:453-459

Karapinar N, Donat R (2009) Adsorption behaviour of $\mathrm{Cu}^{2+}$ and $\mathrm{Cd}^{2+}$ onto natural bentonite. Desalination 249:123-129

Khan TA, Singh VV (2010) Removal of cadmium(II), lead(II), and chromium(VI) ions from aqueous solution using clay. Toxicol Environ Chem 92:1435-1446

Khosravi R, Eslami H, Zarei A, Heidari M, Norouzian-Baghani Abbas, Safavi N, Mokammel A, Fazlzadeh M, Adhami S (2018) Comparative evaluation of nitrate adsorption from aqueous solutions using green and red local montmorillonite adsorbents. Desalin Water Treat 116:119-128

Liao J, Ru X, Xie B, Zhang W, Wu H, Wu C, Wei C (2017) Multiphase distribution and comprehensive ecological risk assessment of heavy metal pollutants in a river affected by acid mine drainage. Ecotoxicol Environ Saf 141:75-84

Măicăneanu A, Bedelean H, Ardelean M, Burcă S, Stanca M (2013) Haneş and Valea Vinului (Romania) closed mines acid mine drainages (AMDs)-actual condition and passive treatment remediation proposal. Chemosphere 93:1400-1405

Malamis S, Katsou E (2013) A review on zinc and nickel adsorption on natural and modified zeolite, bentonite and vermiculite: examination of process parameters, kinetics and isotherms. J Hazard Mater 252:428-461

McCauley CA, O'Sullivan AD, Milke MW, Weber PA, Trumm DA (2009) Sulfate and metal removal in bioreactors treating acid mine drainage dominated with iron and aluminum. Water Res 43:961-970

Melichová Z, Hromada L (2013) Adsorption of $\mathrm{Pb}^{2+}$ and $\mathrm{Cu}^{2+}$ Ions from aqueous solutions on natural bentonite. Pol J Environ Stud $22: 457-464$

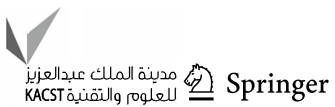


Mohan D, Chander S (2006) Removal and recovery of metal ions from acid mine drainage using lignite - a low cost sorbent. J Hazard Mater 137:1545-1553

Motsi T, Rowson N, Simmons M (2009) Adsorption of heavy metals from acid mine drainage by natural zeolite. Int J Miner Process 92:42-48

Pereira de Araujo AL, Bertagnolli C, Carlos da Silva MG, Gimenes ML, Simões Dornellas de Barros MA (2013) Zinc adsorption in bentonite clay: influence of $\mathrm{pH}$ and initial concentration. Acta Sci Technol 35:325-332

Rafati L, Ehrampoush MH, Rafati AA, Mokhtari M, Mahvi AH (2016) Modeling of adsorption kinetic and equilibrium isotherms of naproxen onto functionalized nano-clay composite adsorbent. J Mol Liq 224:832-841

Rafati L, Ehrampoush M, Rafati A, Mokhtari M, Mahvi A (2018a) Removal of ibuprofen from aqueous solution by functionalized strong nano-clay composite adsorbent: kinetic and equilibrium isotherm studies. Int J Environ Sci Technol 15:513-524

Rafati L, Ehrampoush MH, Rafati AA, Mokhtari M, Mahvi AH (2018b) Nanocomposite adsorbent based on $\beta$-cyclodextrin-PVPclay for the removal of naproxen from aqueous solution: fixed-bed column and modeling studies. Desalin Water Treat 132:63-74

Rakotonimaro TV, Neculita CM, Bussière B, Benzaazoua M, Zagury GJ (2017) Recovery and reuse of sludge from active and passive treatment of mine drainage-impacted waters: a review. Environ Sci Pollut Res 24:73-91

Rios CA, Williams CD, Roberts CL (2008) Removal of heavy metals from acid mine drainage (AMD) using coal fly ash, natural clinker and synthetic zeolites. J Hazard Mater 156:23-35

Sánchez-Andrea I, Sanz JL, Bijmans MF, Stams AJ (2014) Sulfate reduction at low $\mathrm{pH}$ to remediate acid mine drainage. J Hazard Mater 269:98-109

Saravanan D, Gomathi T, Sudha P (2013) Sorption studies on heavy metal removal using chitin/bentonite biocomposite. Int J Biol Macromol 53:67-71
Sen TK, Gomez D (2011) Adsorption of zinc $\left(\mathrm{Zn}^{2+}\right)$ from aqueous solution on natural bentonite. Desalination 267:286-294

Tolonen E-T, Sarpola A, Hu T, Rämö J, Lassi U (2014) Acid mine drainage treatment using by-products from quicklime manufacturing as neutralization chemicals. Chemosphere 117:419-424

Uddin MK (2017) A review on the adsorption of heavy metals by clay minerals, with special focus on the past decade. Chem Eng J 308:438-462

Vieira M, Neto AA, Gimenes M, Da Silva M (2010a) Removal of nickel on Bofe bentonite calcined clay in porous bed. J Hazard Mater 176:109-118

Vieira M, Neto AA, Gimenes M, Da Silva M (2010b) Sorption kinetics and equilibrium for the removal of nickel ions from aqueous phase on calcined Bofe bentonite clay. J Hazard Mater 177:362-371

Zacaroni LM, Magriotis ZM, das Graças Cardoso M, Santiago WD, Mendonça JG, Vieira SS, Nelson DL (2015) Natural clay and commercial activated charcoal: properties and application for the removal of copper from cachaça. Food Control 47:536-544

Zhang M (2011) Adsorption study of $\mathrm{Pb}(\mathrm{II}), \mathrm{Cu}(\mathrm{II})$ and $\mathrm{Zn}$ (II) from simulated acid mine drainage using dairy manure compost. Chem Eng J 172:361-368

Zhu R, Chen Q, Zhou Q, Xi Y, Zhu J, He H (2016) Adsorbents based on montmorillonite for contaminant removal from water: a review. Appl Clay Sci 123:239-258

Publisher's Note Springer Nature remains neutral with regard to jurisdictional claims in published maps and institutional affiliations. 